\title{
CONTRIBUIÇÃO À GEOLOGIA E PETROLOGIA DA REGIÃO DE SÃO DOMINGOS, GO
}

\author{
NOEVALDO ARAÚJO TEIXEIRA*, ALFREDO JOSÉ CUPERTINO POLI* e \\ MARIA CELENE BARBOSA FERREIRA*
}

\begin{abstract}
The São Domingos Sequence (NE of Goiás State), previously considered as belonging to the Araxá Group, is characterized as a small metamorphic belt of the greenschist facies, locally sectioned by plutonic bodies (stocks) of granitic and tonalitic composition. It is underlain by the gneiss-migmatitic sialic basement and is unconformably overlain by carbonate sediments of the Bambui Group.

The sequence consists of muscovite-garnet-biotite schists, feldspathic schists, biotite-calcite-muscovite schists, amphybole schists, biotite phyllites, graphite phyllites, and ferrous quartzites. These rocks were probably derived from an assemblage of sedimentary (greywacke, pelite, ironstone) and basic and acid volcanic rocks, the latter chemically characterized as being respectively of continental tholeitic and calcalkaline types.

The sequence shows a volcano-sedimentary assemblage, which differs greatly from those of the Araxá Group and its lateral facies (Araí, Natividade, and Canastra Groups). In addition, the occurence of acid plutonism, uncommon within those units, leads to a possible correlation with the Ticunzal Formation.
\end{abstract}

INTRODUÇÃo O conjunto metamórfico aqui enfocado localiza-se na porção centro-leste 'do Estado de Goiás, entre as cidades de São Domingos e Galheiros. Aflora como uma faixa estreita de direção $\mathrm{N}-\mathrm{S}$, coberta a oeste pelo Grupo Bambuí e a leste pela Formação Urucuia (Ladeira et al., 1971).

Os trabalhos de prospecção por concentrados de bateia e considerações geológicas preliminares desenvolvidas por Pereira (1976, inédito) revelaram áreas anômalas para o elemento estanho e a possibilidade de existência de rochas vulcânicas no conjunto litológico prospectado. De posse desses dados, a Metais de Goiás S.A. requereu algumas áreas para maior detalhamento.

Com os novos dados geológicos obtidos julgou-se de interesse discutir, entre outros assuntos, a natureza geológica da seqüência, sua ambiência geotectônica e seu posicionamento estratigráfico regional. Com o estudo petroquímico foi possível obter uma separação mais segura dos vários tipos litológicos, sua filiação química, ambiente geológico e, conseqüentemente, sua potencialidade econômica.

Trabalhos anteriores Pouco se conhece sobre a geologia do conjunto metamórfico supracrustal da região de São Domingos-Galheiros. Barbosa et al. (1969) descreveram, nessa região, um conjunto de metamorfitos e plutonitos pré-cambrianos recobertos discordantemente, a oeste, por calcários e silexitos da Formação Paraopeba (Grupo Bambuí), a leste por arenitos da Formação Urucuia (Cretáceo Superior) e areias coluviais e limitados a norte e a sul por gnaisses biotíticos do Complexo Basal. Tal seqüência foi considerada duvidosamente por esses autores como pertencente ao Grupo Araxá.

GEOLOGIA LOCAL A área estudada corresponde a uma faixa estreita e alongada de baixo grau metamórfico, limitada a sul e a norte pelos gnaisses e migmatitos do Complexo Basal. A oeste é recoberta pelos metassedimentos carbona- tados do Grupo Bambuí e a leste, pela Formação Urucuia (Fig. 1).

Suas relações de contato são obviamente discordantes não só pela caracterização do hiato metamórfico entre a faixa estudada e o embasamento mas também pela visível discordância estrutural e metamórfica com o Grupo Bambuí. A seqüência estudada acha-se dobrada em isoclinal, com várias fases de deformação superimpostas, enquanto o Grupo Bambuí dispõe-se sub-horizontalmente em posicionamento tipicamente plataformal.

Por suas feições litológicas, e por esta faixa metamórfica (de baixo grau) apresentar características evolutivas próprias e ambiência geológica individualizada, optou-se por uma denominação informal de Seqüência de São Domingos para que futuramente, com a continuidade dos estudos de mapeamento e geocronologia, possa ser, então, definitivamente caracterizada.

Do ponto de vista litológico, esta seqüência é constituída por diferentes tipos de micaxistos finos, filitos e anfibólio xisto, originalmente representados por grauvacas (feldspáticas, líticas e quartzosas), pelitos tufáceos, vulcânicas básicas e ácidas, pelitos e cherts ferruginosos. A suíte plutônica nela embutida é nitidamente tardia, sendo constituída por corpos circulares de tonalito e granito, localmente com efeitos de metamorfismo de contato. Ocorrem ainda sills e diques de microtonalito.

Em função da escassez de afloramentos, não há possibilidade de seções contínuas, o que dificulta o empilhamento estratigráfico. Além disso, as deformações tectônicas são acentuadas, com estilo isoclinal verticalizado. Por essa razão, a reconstrução da coluna aqui proposta deve ser encarada apenas como uma tentativa inicial.

A seqüência apresenta enérgico padrão de deformação, destacando-se isoclinais apertadas com planos axiais verticalizados. Os corpos plutônicos empreenderam, quando de seus posicionamentos, reorientações nos principais lineamentos estruturais, o que evidentemente dificulta a hierarquização das três fases de deformação identificadas. As ati- 

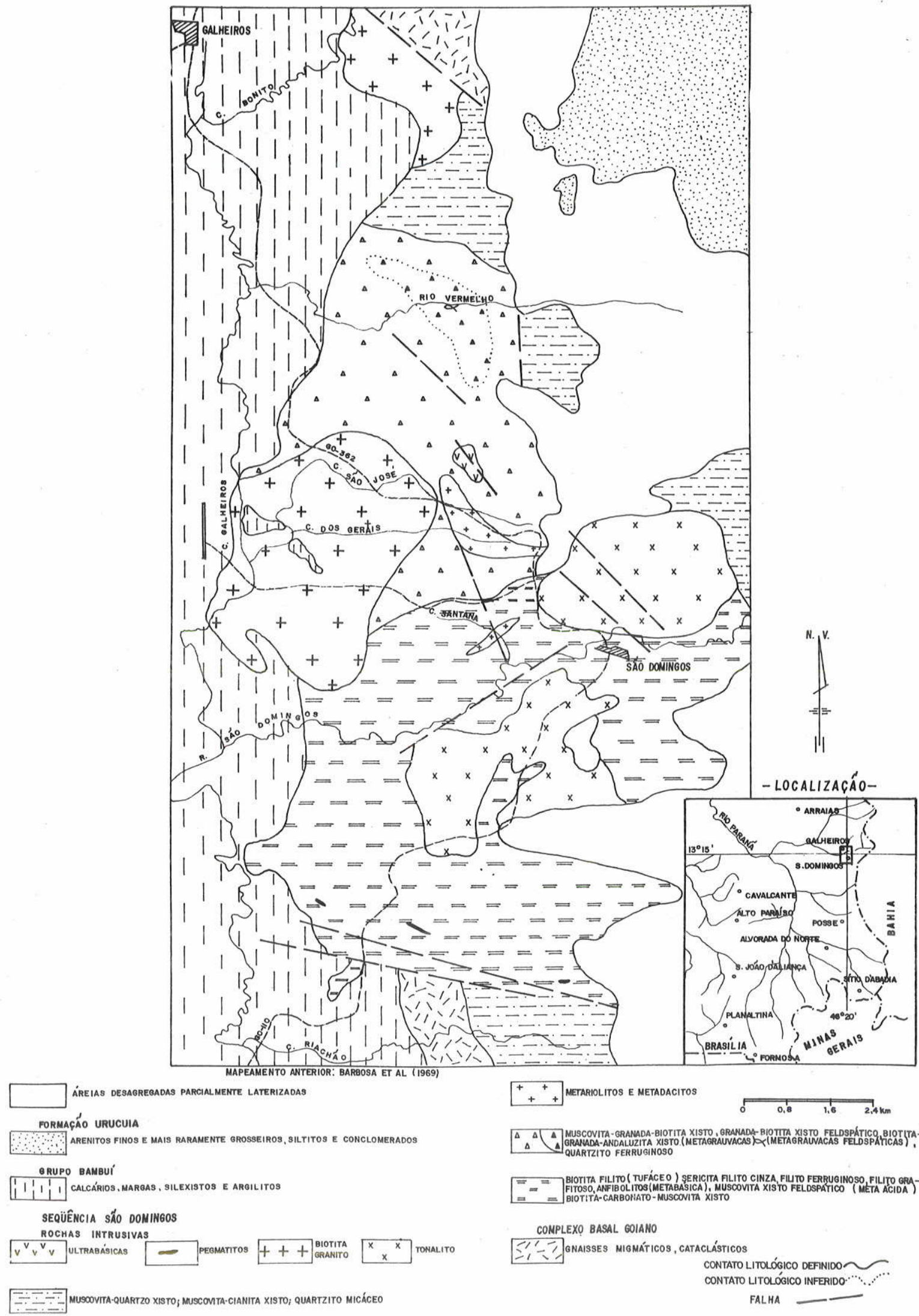
tudes da xistosidade na porção sul da área possuem direção próxima a $\mathrm{E}-\mathrm{W}$, com mergulhos altos, quase sempre acima de $70^{\circ}$. Na porção norte, as atitudes estão sempre com direção próxima a N30-40W e mergulhos altos para o quadrante NE.

A seqüência foi preliminarmente dividida em duas porções obedecendo-se critérios litológicos e diferenças em termos de sedimentação original.

Unidade basal Ocorre na porção sudoeste da área, estendendo-se do Córrego Bonito a pouco ao sul do Córrego dos Gerais. Em sua porção oeste, esta unidade é secionada por um corpo granítico circular, sendo ambos cobertos, discordantemente, por silexitos e calcários do Grupo Bambuí. Constitui-se de biotita filito, biotita-carbonato-muscovita xisto, muscovita xisto feldspático (meta-ácida), epídoto-actinolita xisto (metabásica), sericita filito cinza, filito ferruginoso, filito grafitoso e quartzitos ferruginosos.

Os biotita filitos, sejam eles de origem tufácea ou não, apresentam-se como rochas de granulação fina e proeminente estrutura foliada. Nos termos considerados como tufáceos são identificadas diminutas pontuações de cor branca e fragmentos (?) com tamanho em torno de 0,5 a $2 \mathrm{~mm}$. Microscopicamente, essas litologias apresentam às vezes diminutos cristais de feldspato e quartzo, alguns com formas tabulares que lembram cristais originalmente vulcânicos (Foto 1). Daí a possibilidade de que este nível se tenha formado por contribuição vulcanoclástica fina.

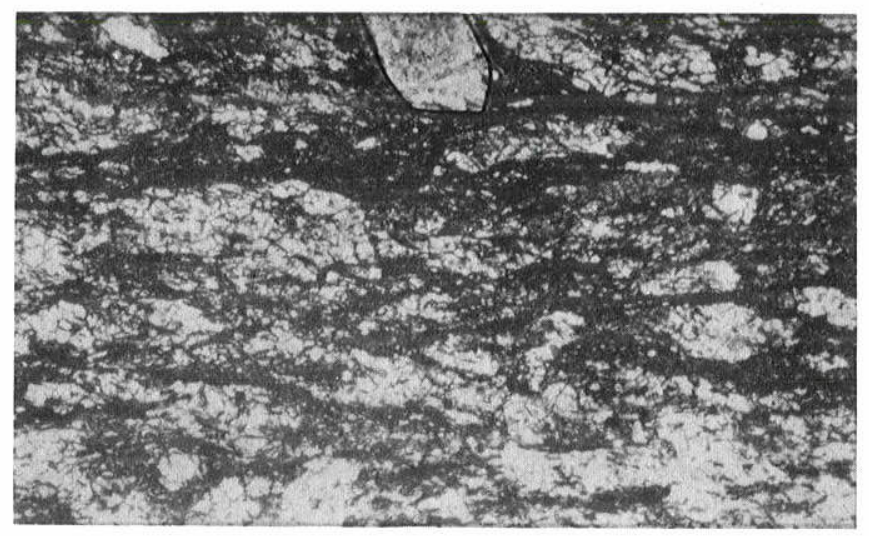

Foto 1 - Filito tufáceo. Na porşão superior da foto, cristal de plagioclásio tabular com tendências ao idiomorfismo. N.X, $12 \mathrm{X}$

Os biotita-carbonato-muscovita xistos fazem parte dos níveis de origem vulcânica de composição ácida. Estes ainda não estão seguramente posicionados na estratigrafia tampouco seus reais limites cartográficos são conhecidos. Ocorre com maior extensão do sul da ponte sobre o Córrego Santana, passando pela cabeceira do Córrego dos Gerais, ao Córrego São José.

São normalmente rochas de granulação fina, coloração cinza e estrutura maciça (exceto os níveis mais xistificados). Macroscopicamente, é possível identificar com facilidade cristais ripiformes de feldspato, típicos fenocristais tectonicamente rotacionados. Ao microscópio, o fabric metamórfico granoblástico constitui a principal feição textural. Os fenocristais ocorrem imersos nesta matriz fina recristalizada, conservando formas euédricas e padrão de geminação segundo a lei da albita (plagioclásios) e Carlsbad (ortoclásio) (Foto 2). Os antigos fenocristais de quartzo apresentam-se como pequenos agregados granoblásticos recristalizados.

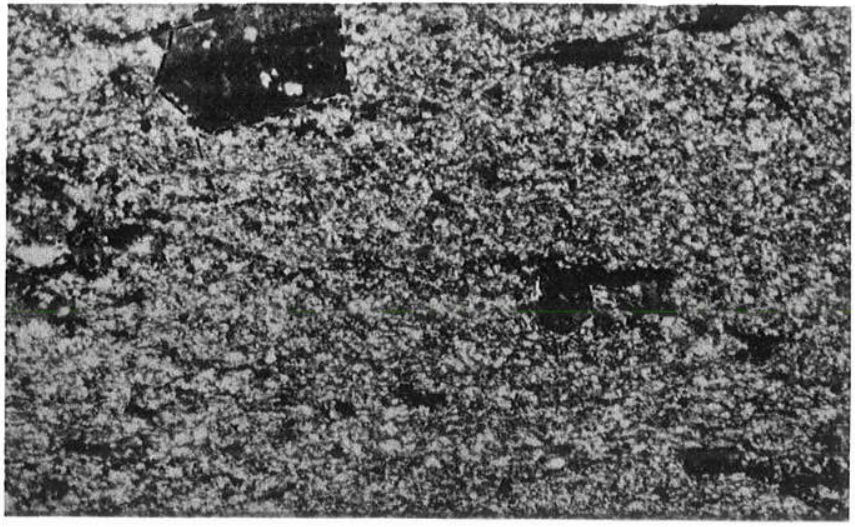

Foto 2-Metavulcânica ácida. Fenocristais de feldspato imersos em matriz granoblástica fina. N.X, $12 X$

O conjunto de sericita filitos cinza, filitos ferruginosos, quartzitos ferruginosos e filitos grafitosos é considerado como sendo de natureza sedimentar. Aparentemente, a sedimentação é predominantemente detrítica argilosa. Os níveis estreitos de quartzitos finos com lâminas de óxido de ferro podem representar originalmente estratos silicosos químicos (cherts).

O conjunto de filitos cinza é bastante caracteristico no campo. São rochas fortemente crenuladas, com granulação fina e evidenciando normalmente três fases de deformação. Intercaladas e intrusivas nesse pacote ocorrem restritas manifestações vulcânicas de caráter básico, retratadas pela ocorrência de níveis estreitos de epídoto-anfibólio xistos ou anfibolitos de granulação fina, estrutura xistosa e cor verde. Embora a textura presente seja nitidamente metamórfica (Foto 3), localmente foram constatadas feições amigdaloidais ainda preservadas.

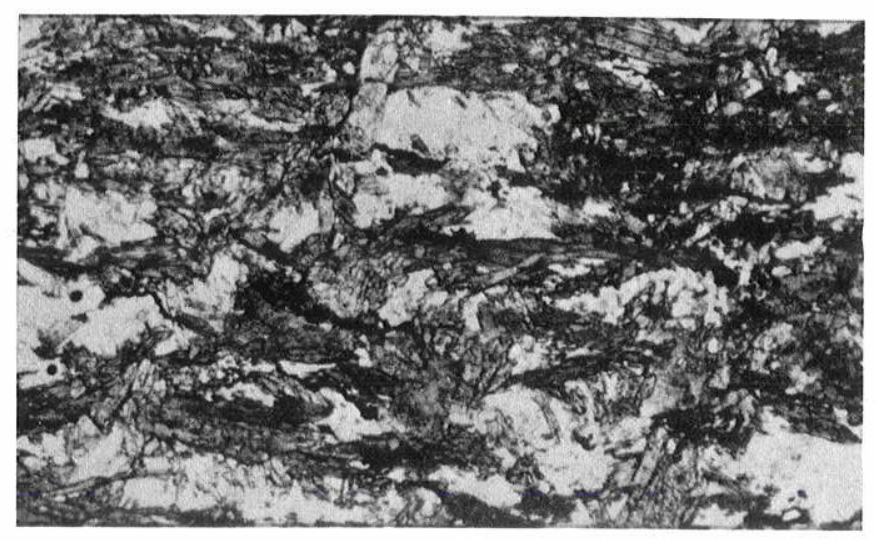

Foto 3-Anfibólio xisto com textura nematoblástica. N.//, $12 X$

Ao microscópio, os filitos apresentam textura lepidoblástica sem qualquer feição textural primária conservada. A alternância regular de lâminas de quartzo e muscovita sugere uma deposição rítmica originalmente sedimentar. Sobre os estratos acima descritos ocorre um conjunto de quartzo-muscovita xistos localmente com cianita e quartzitos micáceos aflorantes nas porções sul e nortc da área, cujo posicionamento estratigráfico não se acha perfeitamente estabelecido. Representam originalmente uma sedimentação pelítica hiperaluminosa e arenosa que difere bastante dos estratos inferiores, nitidamente formados a partir de sedimentos imaturos. 
Unidade superior Ocorre do sul do Córrego dos Gerais ao norte do Rio Vermelho na porção norte da área. É constituída fundamentalmente por um conjunto de muscovita-granada-biotita xisto, granada-biotita-andaluzita xisto, granada-biotita-xisto feldspático e biotita-quartzo xisto.

Tais litologias foram reconstituídas como componentes de um antigo pacote sedimentar predominantemente imaturo, de natureza arenosa impura (grauvaca), com intercalações pelíticas. É representada por rochas de coloração cinza-escura, granulação fina e estrutura xistosa bem desenvolvida. Obviamente, o estabelecimento de tal estrutura é dependente da maior ou menor participação de biotita e quartzo. Algumas vezes ocorrem fragmentos de rochas de cor cinza-escuro de natureza grafitosa. Os biotita-muscovita-andaluzita xistos ocorrem principalmente como franjas aureolando os corpos ácidos intrusivos. Em afloramento é possível constatar porfiroblastos de até $3 \mathrm{~cm}$ de andaluzita. Tais cristais, em lâmina, mostram uma cristalização pós-tectônica (Foto 4).

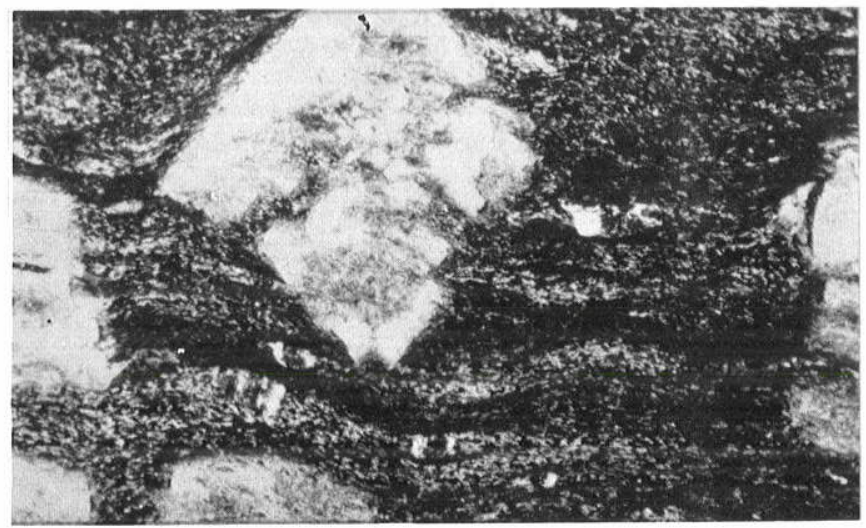

Foto 4-Andaluzita-biotita xisto. Porfiroblastos de andaluzita englobam as mesmas feiçôes da matriz lepidoblástica. N.X, $12 \mathrm{X}$

Em afloramento, as metagrauvacas ocorrem em bancos bem definidos, onde se alternam porções feldspáticas, líticas e quartzosas. Localmente é possível observar a passagem de metagrauvacas feldspáticas (níveis mais estreitos) para metagrauvacas arenosas. $\mathrm{O}$ grau de maturidade do pacote como um todo é bastante variável, sendo possível (norte da área mapeada, Fig. 1) individualizar uma porção composicional e texturalmente mais imatura, na qual predominam clastos de feldspatos sobre grãos de quartzo. Os componentes detríticos apresentam-se angulosos ou subarredondados, indicando uma limitada ação abrasiva (Fotos 5, 6 e 7).

As principais características que permitiram identificar tais litologias como originalmente sedimentares detríticas foram a ausência de qualquer textura ou cristais vulcânicos, a presença de acamamento gradacional, laminação plano-paralela e de fragmentos de cristais de quartzo, feldspato e de rocha, todos de proveniência sedimentar.

As metagrauvacas apresentam matrız de silte com mesma composição dos fragmentos. A relação matriz-fragmentos é bastante variável, ocorrendo exemplos em que há nítida predominância de clastos. Embora não seja tão freqüente, ocorrem fragmentos angulosos de rocha de natureza grafitosa. Os fragmentos de quartzo são de tipo monocristalino e policristalino. Os efeitos tectônicos pós-deposicionais são retratados principalmente pela extinção ondulante nos grãos de quartzo.

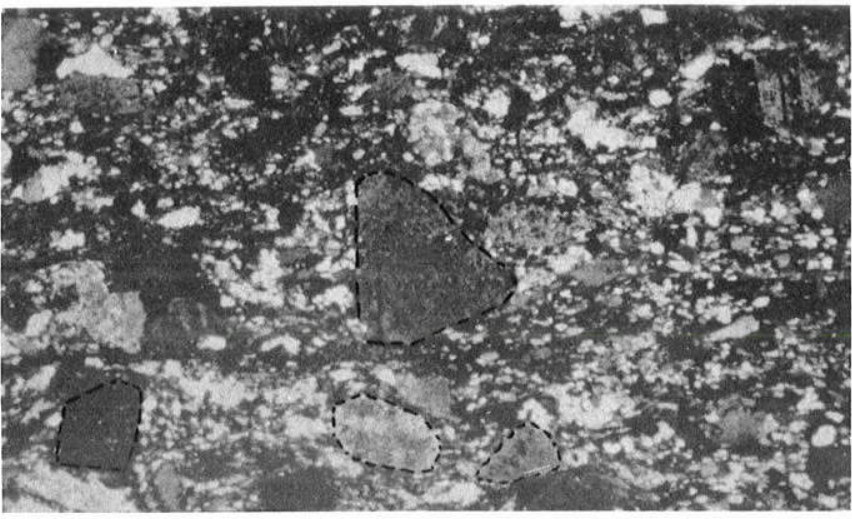

Foto 5-Metagrauvaca Clastos subangulosos de feldspato orientados pela deformação tectônica. N.X, 12 X

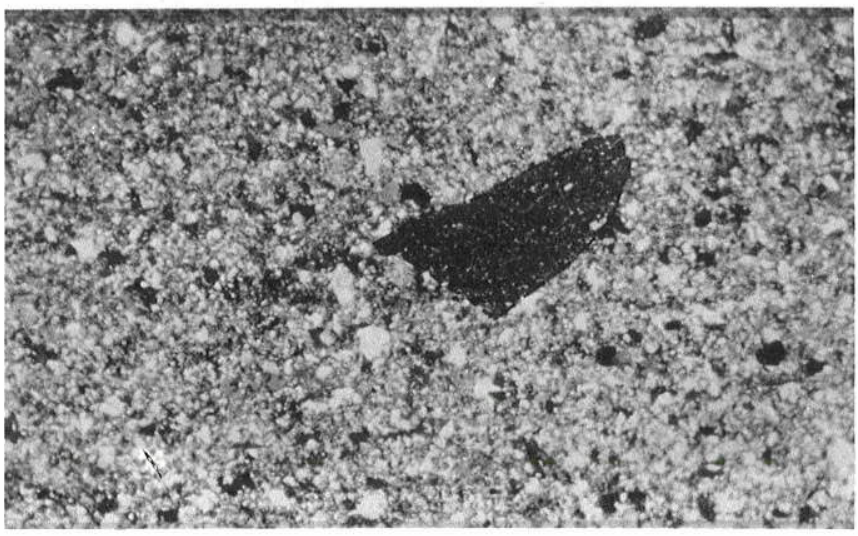

Foto 6 - Metagrauvaca. Clastos de feldspato e quartzo de granulação média a fina e fragmentos de rocha (no centro da foto). N.X, $12 X$

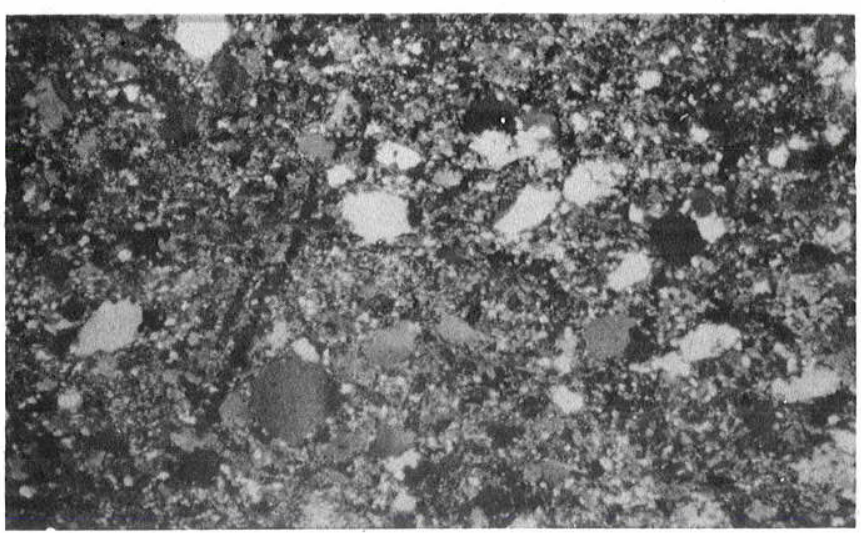

Foto 7 - Metagrauvaca. Predominância de clastos sobre a matriz. N.X, $12 X$

Concluindo, a disposiçâo e à morfologia dos componentes formadores dos xistos com biotita, granaóa, muscovita, quartzo e feldspato encontrados principalmente no leito do Rio Vermelho indicam uma proveniência sedimentar detrítica, em que o mau selecionamento e o retrabalhamento dos componentes imaturos sugerem um rápido preenchimento da bacia de deposição.

A suíte plutônica, já descrita por Barbosa et al. (1969), é representada por intrusões circulares e diques de tonalito localizados a norte e sudoeste da cidade de São Domingos. e um corpo granítico circular com diâmetro de $5 \mathrm{~km}$ na 
porção oeśte da área mapeada. Ao microscópio, essas rochas mostram texturas ígneas muito bem preservadas (Fotos 8 e 9). A ausência de foliações e recristalizações em grande escala sugere um posicionamento pós-tectônico para esses corpos. Os tonalitos apresentam cristais tabulares idiomórficos ou hipidiomórficos de oligloclásio envolvidos por quartzo xenomórfico. Aparentemente, o feldspato calco-sódico cristalizou-se precocemente. A hornblenda constitui o principal acessório. Os biotita granitos localmente podem passar para muscovita granitos. São rochas granulares hipidiomórficas, com feições cataclásticas bem caracterizadas. Manifestações ácidas residuais são subordinadamente representadas por greisens e pegmatitos com cassiterita encontrados na porção sul da área.

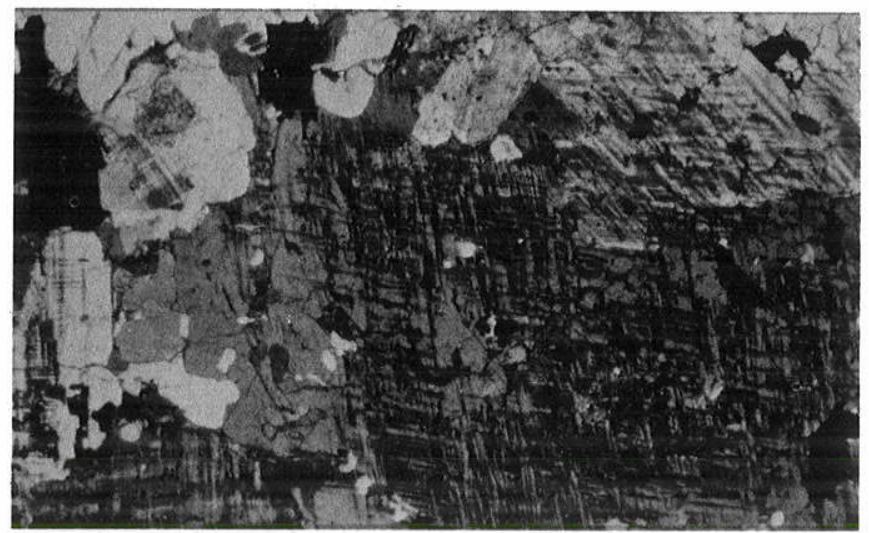

Foto 8 - Biotita granito. Textura granular hipidiomórfica com recristalizaşão nas margens dos cristais precocemente formados. N.X, $12 X$

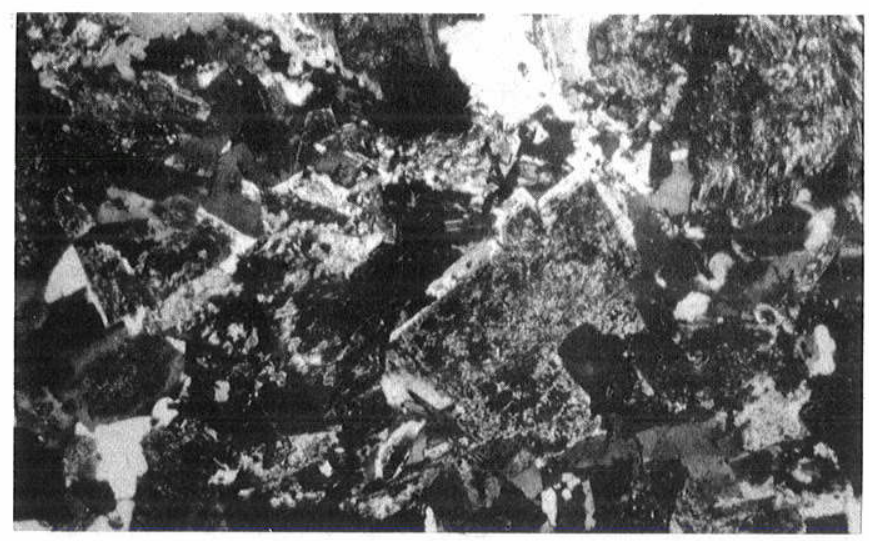

Foto 9 - Tonalito. Predominância de plagioclásio em ripas bem formadas. N.X, $12 \mathrm{X}$

\section{PETROLOGIA Reconstituição das litologias ori-} ginais Para que as considerações petroquímicas tenham validade, é necessário que o quimismo original das rochas analisadas não tenha sido fundamentalmente modificado. Em relação às rochas metabásicas de São Domingos, os diagramas das Figs. 2 e 3 mostram que a premissa de uma inalteração química primária parece válida. Desta forma, a partir das análises químicas de rocha (Tab. 1), foi tentado reconstituir os tipos litológicos originais, empregando os trabalhos de La Roche (1968) e Moine e de La Roche (1968), nos quais os autores desenvolveram métodos estatísticos vi-

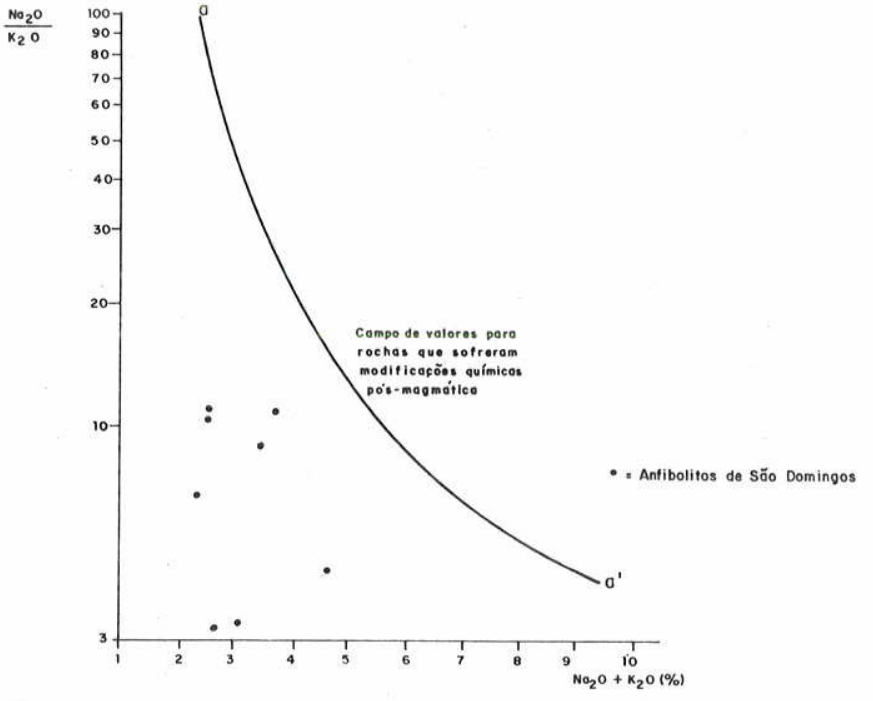

Figura 2 - Diagrama de Miyashiro (1975) no qual a linha $a-a^{\prime}$ representa o limite superior $\mathrm{N}_{2} \mathrm{O} / \mathrm{K}_{2} \mathrm{O}$ para rochas vulcânicas inalteradas. As rochas originalmente básicas de São Domingos aparentemente não sofreram perda de alcalinos

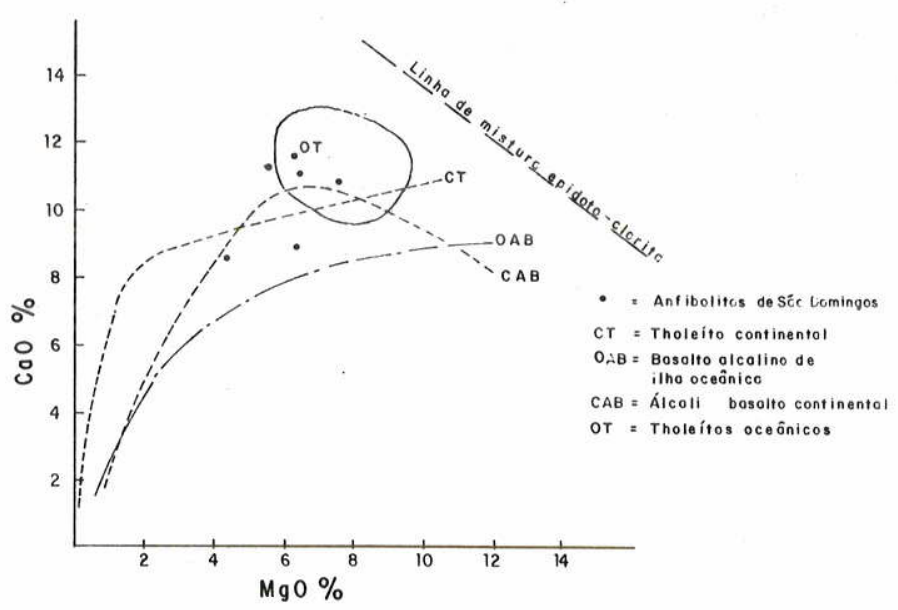

Figura 3 - Diagrama de Floyd (1976) que permite avaliar o grau de modificasões quimicas secundárias e os principais trends vulcânicos. Rochas alteradas formam trends aproximadamente paralelos à linha de misturas epidoto-clorita. Esse não é o caso das rochas anfiboliticas de São Domingos

sando a atribuir a cada família de rochas variáveis químicas que expressassem associações mineralógicas. Como conseqüência, são deduzidas funções específicas para cada família estudada por meio de diagramação representativa dessas funções.

A Fig. 4 avalia o comportamento petroquímico do $\mathrm{K}$, $\mathrm{Na}$ e $\mathrm{Al}$ nas séries vulcânicas comuns e rochas sedimentares. Nas séries vulcânicas, as relações $\mathrm{Na} / \mathrm{Al}$ e K/Al crescem ao mesmo tempo, das básicas para as ácidas. Ao contrário, no ciclo de superfície, ocorrem enérgicas diminuições da relação $\mathrm{Na} / \mathrm{Al}$ enquanto o $\mathrm{K}$ permanece ligado ao $\mathrm{Al}$. A bissetriz, representada em traço cheio, separa campos em que $\mathrm{Na}>\mathrm{K}$ e Na $<\mathrm{K}$, vulcânico e sedimentar, respectivamente. As rochas vulcânicas dispõem-se ao lado dos valores fracos de $\mathrm{Al} / 3-\mathrm{Na}$, sendo possível estabelecer a distinção entre as séries ígneas calco-alcalina (pacífica) e alcalina (atlântica). O campo sedimentar é bem definido, com calcários e arenitos convergindo para a origem, e com folhelhos, sedimentos confinados e arcósios divergindo em feixe, a partir da origem. 
Tabela 1-Análises quimicas e classificação das rochas da Região de São Domingos (Laboratório do Centro de Tecnologia Mineral - METAGO)

\begin{tabular}{|c|c|c|c|c|c|c|c|c|c|c|c|c|c|c|}
\hline $\mathbf{A M}$ & OSTRA & $\mathrm{SiO}_{2}$ & $\mathbf{A l}_{2} \mathbf{O}_{3}$ & $\mathrm{Fe}_{2} \mathrm{O}_{3}$ & $\mathrm{FeO}$ & MgO & $\mathrm{CaO}$ & $\mathrm{Na}_{2} \mathrm{O}$ & $\mathbf{K}_{2} \mathbf{O}$ & $\mathrm{TiO}_{2}$ & $\mathbf{P}_{2} \mathbf{O}_{5}$ & MnO & P.F. & TOTAL \\
\hline 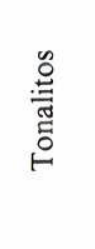 & $\begin{array}{l}01 \\
02 \\
03 \\
04 \\
05 \\
06 \\
07\end{array}$ & $\begin{array}{l}56,2 \\
57,7 \\
58,0 \\
63,1 \\
59,9 \\
54,4 \\
58,7\end{array}$ & $\begin{array}{l}12,3 \\
15,0 \\
12,6 \\
15,0 \\
14,2 \\
13,5 \\
15,8\end{array}$ & $\begin{array}{l}6,65 \\
5,97 \\
7,11 \\
5,05 \\
6,65 \\
8,26 \\
3,06\end{array}$ & $\begin{array}{l}4,21 \\
3,57 \\
4,37 \\
2,85 \\
3,49 \\
4,87 \\
6,25\end{array}$ & $\begin{array}{l}7,45 \\
5,64 \\
5,64 \\
2,41 \\
5,64 \\
6,45 \\
3,83\end{array}$ & $\begin{array}{l}4,76 \\
5,00 \\
5,0 \\
3,36 \\
4,20 \\
6,72 \\
1,32\end{array}$ & $\begin{array}{l}3,80 \\
2,98 \\
4,26 \\
4,32 \\
3,02 \\
2,89 \\
1,23\end{array}$ & $\begin{array}{l}0,99 \\
0,75 \\
0,68 \\
2,28 \\
0,92 \\
0,67 \\
2,96\end{array}$ & $\begin{array}{l}0,10 \\
0,35 \\
0,26 \\
0,61 \\
0,45 \\
0,52 \\
1,20\end{array}$ & $\begin{array}{l}0,10 \\
0,09 \\
0,09 \\
0,15 \\
0,10 \\
0,10 \\
0,12\end{array}$ & $\begin{array}{l}0,12 \\
0,12 \\
0,01 \\
0,10 \\
0,14 \\
0,18 \\
0,15\end{array}$ & $\begin{array}{l}4,05 \\
1,90 \\
2,0 \\
1,65 \\
1,95 \\
2,00 \\
3,50\end{array}$ & $\begin{array}{r}100,73 \\
99,07 \\
100,20 \\
100,88 \\
100,66 \\
100,56 \\
98,12\end{array}$ \\
\hline 葋 & $\begin{array}{l}08 \\
09 \\
10 \\
11\end{array}$ & $\begin{array}{l}71,2 \\
70,2 \\
69,0 \\
70,6\end{array}$ & $\begin{array}{l}13,6 \\
13,3 \\
14,1 \\
14,1\end{array}$ & $\begin{array}{l}2,29 \\
3,67 \\
2,98 \\
2,29\end{array}$ & $\begin{array}{l}0,99 \\
1,73 \\
1,96 \\
0,99\end{array}$ & $\begin{array}{l}1,00 \\
1,00 \\
1,61 \\
1,00\end{array}$ & $\begin{array}{l}0,10 \\
0,14 \\
0,17 \\
0,11\end{array}$ & $\begin{array}{l}3,76 \\
3,13 \\
3,16 \\
2,88\end{array}$ & $\begin{array}{l}5,38 \\
4,95 \\
5,06 \\
6,19\end{array}$ & $\begin{array}{l}0,28 \\
0,12 \\
0,28 \\
0,13\end{array}$ & $\begin{array}{l}0,03 \\
0,07 \\
0,07 \\
0,07\end{array}$ & $\begin{array}{l}0,03 \\
0,06 \\
0,05 \\
0,05\end{array}$ & $\begin{array}{l}0,55 \\
1,15 \\
0,85 \\
0,60\end{array}$ & $\begin{array}{l}99,21 \\
99,52 \\
99,29 \\
99,01\end{array}$ \\
\hline 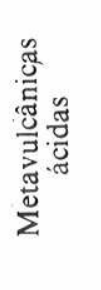 & $\begin{array}{l}12 \\
13 \\
14 \\
15 \\
16 \\
17 \\
18 \\
19\end{array}$ & $\begin{array}{l}76,2 \\
63,6 \\
64,3 \\
71,8 \\
69,7 \\
70,9 \\
72,0 \\
71,7\end{array}$ & $\begin{array}{l}11,8 \\
14,8 \\
15,9 \\
14,5 \\
16,5 \\
13,4 \\
14,1 \\
13,7\end{array}$ & $\begin{array}{l}1,99 \\
4,27 \\
2,57 \\
2,22 \\
1,99 \\
1,74 \\
1,97 \\
2,92\end{array}$ & $\begin{array}{l}1,65 \\
3,69 \\
3,07 \\
1,00 \\
1,67 \\
1,65 \\
2,96 \\
0,85\end{array}$ & $\begin{array}{l}1,41 \\
2,62 \\
1,61 \\
0,60 \\
1,00 \\
0,80 \\
1,41 \\
1,20\end{array}$ & $\begin{array}{l}0,19 \\
1,40 \\
3,30 \\
1,68 \\
2,24 \\
1,96 \\
0,22 \\
0,24\end{array}$ & $\begin{array}{l}2,64 \\
1,49 \\
2,46 \\
2,98 \\
3,19 \\
3,-6 \\
3,20 \\
3,07\end{array}$ & $\begin{array}{l}1,48 \\
1,13 \\
2,39 \\
1,52 \\
1,30 \\
1,63 \\
1,16 \\
3,37\end{array}$ & $\begin{array}{l}0,64 \\
1,10 \\
1,10 \\
0,59 \\
0,58 \\
0,59 \\
0,63 \\
0,53\end{array}$ & $\begin{array}{l}0,02 \\
0,05 \\
0,18 \\
0,04 \\
0,05 \\
0,06 \\
0,03 \\
0,04\end{array}$ & $\begin{array}{l}0,07 \\
0,15 \\
0,12 \\
0,09 \\
0,10 \\
0,10 \\
0,14 \\
0,09\end{array}$ & $\begin{array}{l}1,20 \\
4,80 \\
1,60 \\
1,30 \\
0,90 \\
0,90 \\
1,60 \\
1,80\end{array}$ & $\begin{array}{l}99,29 \\
99,10 \\
98,60 \\
98,32 \\
99,22 \\
98,29 \\
99,47 \\
99,51\end{array}$ \\
\hline 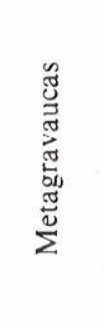 & $\begin{array}{l}20 \\
21 \\
22 \\
23 \\
24 \\
25 \\
26 \\
27 \\
28\end{array}$ & $\begin{array}{l}65,0 \\
64,1 \\
64,3 \\
72,3 \\
65,6 \\
62,9 \\
61,5 \\
62,6 \\
68,0\end{array}$ & $\begin{array}{l}10,6 \\
12,6 \\
14,0 \\
13,9 \\
13,9 \\
16,9 \\
16,0 \\
16,9 \\
14,0\end{array}$ & $\begin{array}{l}7,57 \\
7,34 \\
6,65 \\
2,44 \\
7,73 \\
3,20 \\
2,23 \\
2,31 \\
2,97\end{array}$ & $\begin{array}{l}4,66 \\
2,97 \\
3,98 \\
1,67 \\
3,78 \\
4,40 \\
5,95 \\
4,59 \\
4,00\end{array}$ & $\begin{array}{l}2,82 \\
2,62 \\
1,81 \\
1,20 \\
2,31 \\
1,81 \\
2,82 \\
2,41 \\
1,81\end{array}$ & $\begin{array}{l}1,12 \\
0,10 \\
2,24 \\
0,21 \\
3,73 \\
2,24 \\
1,56 \\
1,68 \\
1,96\end{array}$ & $\begin{array}{l}1,70 \\
0 ; 87 \\
2,80 \\
4,24 \\
3,33 \\
3,16 \\
1,59 \\
2,01 \\
1,62\end{array}$ & $\begin{array}{l}2,92 \\
2,76 \\
2,75 \\
1,53 \\
1,26 \\
1,77 \\
3,26 \\
2,92 \\
2,21\end{array}$ & $\begin{array}{l}0,42 \\
0,66 \\
0,56 \\
0,51 \\
1,02 \\
1,10 \\
1,00 \\
1,00 \\
0,95\end{array}$ & $\begin{array}{l}0,11 \\
0,09 \\
0,10 \\
0,03 \\
0,02 \\
0,08 \\
0,07 \\
0,11 \\
0,11\end{array}$ & $\begin{array}{l}0,11 \\
0,11 \\
0,10 \\
0,09 \\
0,12 \\
0,25 \\
0,14 \\
0,14 \\
0,20\end{array}$ & $\begin{array}{l}2,40 \\
5,30 \\
1,75 \\
1,50 \\
1,40 \\
1,20 \\
3,00 \\
2,40 \\
1,60\end{array}$ & $\begin{array}{r}99,43 \\
99,52 \\
101,06 \\
99,61 \\
100,20 \\
99,01 \\
99,12 \\
99,07 \\
99,43\end{array}$ \\
\hline 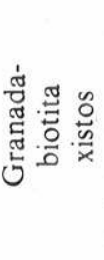 & $\begin{array}{l}29 \\
30 \\
31 \\
32 \\
33 \\
34 \\
35\end{array}$ & $\begin{array}{l}63,8 \\
61,4 \\
59,3 \\
62,8 \\
64,2 \\
56,1 \\
59,4\end{array}$ & $\begin{array}{l}15,5 \\
14,3 \\
18,9 \\
17,5 \\
16,3 \\
18,9 \\
18,1\end{array}$ & $\begin{array}{l}2,19 \\
4,79 \\
2,05 \\
2,12 \\
2,69 \\
3,64 \\
3,33\end{array}$ & $\begin{array}{l}5,99 \\
3,65 \\
6,55 \\
5,19 \\
4,46 \\
6,69 \\
6,01\end{array}$ & $\begin{array}{l}3,00 \\
2,82 \\
2,62 \\
2,21 \\
2,61 \\
3,83 \\
2,62\end{array}$ & $\begin{array}{l}1,40 \\
2,24 \\
0,84 \\
1,12 \\
1,40 \\
0,22 \\
1,68\end{array}$ & $\begin{array}{l}1,44 \\
1,59 \\
1,58 \\
1,66 \\
1,16 \\
1,30 \\
2,05\end{array}$ & $\begin{array}{l}2,45 \\
2,56 \\
2,71 \\
2,71 \\
2,56 \\
3,71 \\
1,86\end{array}$ & $\begin{array}{l}1,10 \\
1,12 \\
1,20 \\
1,10 \\
1,20 \\
0,79 \\
1,20\end{array}$ & $\begin{array}{l}0,03 \\
0,10 \\
0,14 \\
0,05 \\
0,12 \\
0,13 \\
0,01\end{array}$ & $\begin{array}{l}3,00 \\
0,14 \\
0,15 \\
0,10 \\
0,09 \\
0,10 \\
0,18\end{array}$ & $\begin{array}{l}1,70 \\
3,00 \\
3,40 \\
3,00 \\
2,70 \\
3,25 \\
2,70\end{array}$ & $\begin{array}{c}98,75 \\
98,34 \\
99,93 \\
99,56 \\
99,49 \\
98,71 \\
99,23\end{array}$ \\
\hline 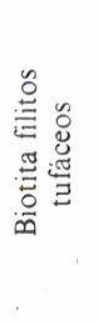 & $\begin{array}{l}36 \\
37 \\
38 \\
39 \\
40 \\
41 \\
42 \\
43 \\
44\end{array}$ & $\begin{array}{l}66,1 \\
60,3 \\
69,9 \\
61,7 \\
61,5 \\
57,1 \\
65,4 \\
60,7 \\
64,6\end{array}$ & $\begin{array}{l}15,0 \\
17,9 \\
12,4 \\
16,3 \\
14,8 \\
21,6 \\
12,4 \\
14,6 \\
15,6\end{array}$ & $\begin{array}{l}3,83 \\
4,64 \\
3,64 \\
7,34 \\
7,30 \\
4,19 \\
8,03 \\
5,97 \\
2,38\end{array}$ & $\begin{array}{l}3,65 \\
3,35 \\
4,25 \\
1,61 \\
1,39 \\
3,11 \\
1,52 \\
3,82 \\
3,24\end{array}$ & $\begin{array}{l}2,01 \\
2,82 \\
1,61 \\
2,21 \\
2,82 \\
1,81 \\
2,82 \\
6,45 \\
1,61\end{array}$ & $\begin{array}{l}0,31 \\
0,89 \\
0,12 \\
1,12 \\
0,76 \\
0,10 \\
0,10 \\
3,64 \\
2,24\end{array}$ & $\begin{array}{l}2,57 \\
0,40 \\
2,60 \\
1,83 \\
1,44 \\
1,17 \\
0,10 \\
3,06 \\
2,89\end{array}$ & $\begin{array}{l}2,51 \\
3,32 \\
2,41 \\
3,18 \\
2,67 \\
3,10 \\
3,35 \\
0,98 \\
2,54\end{array}$ & $\begin{array}{l}0,80 \\
1,00 \\
1,00 \\
0,70 \\
1,20 \\
1,10 \\
0,58 \\
0,47 \\
1,10\end{array}$ & $\begin{array}{l}0,10 \\
0,03 \\
0,05 \\
0,07 \\
0,06 \\
0,03 \\
0,08 \\
0,11 \\
1,16\end{array}$ & $\begin{array}{l}0,11 \\
0,12 \\
0,14 \\
0,11 \\
0,15 \\
0,10 \\
0,06 \\
0,12 \\
0,10\end{array}$ & $\begin{array}{l}2,80 \\
4,90 \\
1,60 \\
4,85 \\
5,30 \\
5,80 \\
4,90 \\
1,75 \\
2,30\end{array}$ & $\begin{array}{r}99,79 \\
99,67 \\
99,72 \\
101,02 \\
99,39 \\
99,21 \\
99,49 \\
101,67 \\
98,76\end{array}$ \\
\hline 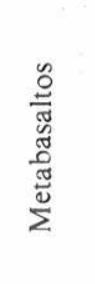 & $\begin{array}{l}45 \\
46 \\
47 \\
48 \\
49 \\
50 \\
51 \\
52\end{array}$ & $\begin{array}{l}44,6 \\
48,1 \\
49,7 \\
46,2 \\
48,0 \\
49,1 \\
51,7 \\
48,6\end{array}$ & $\begin{array}{l}15,2 \\
16,5 \\
16,7 \\
16,1 \\
17,0 \\
14,8 \\
14,0 \\
14,5\end{array}$ & $\begin{array}{l}7,4 \\
7,0 \\
7,6 \\
6,4 \\
7,2 \\
6,9 \\
7,2 \\
6,3\end{array}$ & $\begin{array}{l}6,3 \\
6,3 \\
5,6 \\
7,0 \\
5,0 \\
8,0 \\
8,1 \\
8,1\end{array}$ & $\begin{array}{l}8,06 \\
6,65 \\
6,45 \\
7,66 \\
6,25 \\
5,44 \\
4,43 \\
6,45\end{array}$ & $\begin{array}{r}11,49 \\
10,09 \\
8,97 \\
10,93 \\
11,49 \\
9,25 \\
8,41 \\
8,97\end{array}$ & $\begin{array}{l}2,35 \\
2,31 \\
2,34 \\
2,03 \\
1,99 \\
3,18 \\
3,54 \\
3,66\end{array}$ & $\begin{array}{l}0,71 \\
0,19 \\
0,21 \\
0,63 \\
0,29 \\
0,35 \\
0,31 \\
0,83\end{array}$ & $\begin{array}{l}1,30 \\
1,12 \\
1,16 \\
1,31 \\
0,99 \\
1,57 \\
1,38 \\
1,30\end{array}$ & $\begin{array}{l}0,10 \\
0,14 \\
0,14 \\
0,23 \\
0,13 \\
0,12 \\
0,15 \\
0,11\end{array}$ & $\begin{array}{l}0,19 \\
0,18 \\
0,18 \\
0,18 \\
0,17 \\
0,20 \\
0,21 \\
0,21\end{array}$ & $\begin{array}{l}1,80 \\
0,45 \\
0,65 \\
1,30 \\
0,50 \\
0,90 \\
0,40 \\
1,10\end{array}$ & $\begin{array}{r}99,60 \\
99,03 \\
99,74 \\
99,91 \\
99,01 \\
99,81 \\
99,84 \\
100,13\end{array}$ \\
\hline
\end{tabular}


Para o conjunto metamórfico da região de São Domingos a Fig. 4 mostra pontos dispersos entre os campos vulcânicos e sedimentar. Entre os de proveniência vulcânica é possível, a princípio, separar um grupo de basaltos e outro predominantemente dacítico. Entre o domínio sedimentar predominam os pelitos e, subordinadamente, as grauvacas.

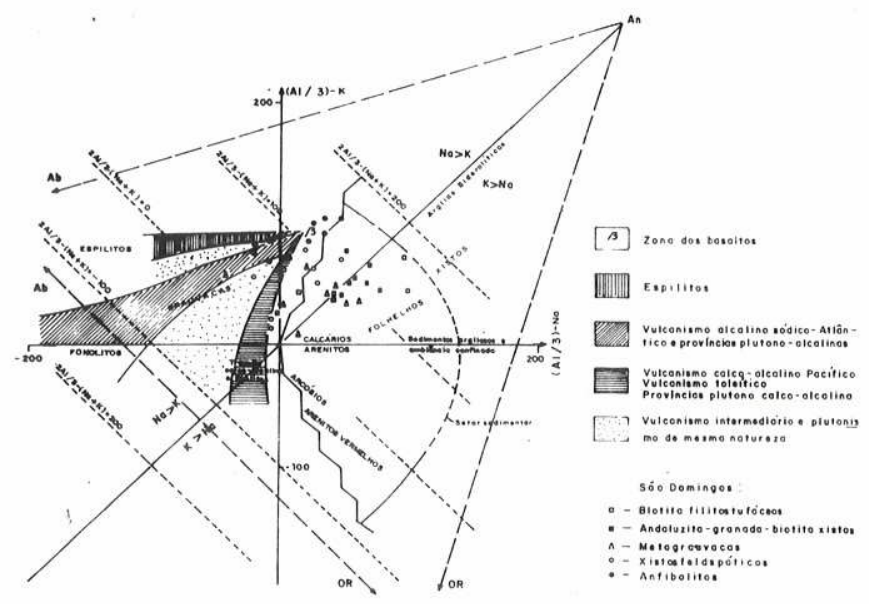

Figura 4-Dominios e tendências vulcânicas e sedimentares em função do comportamento diferencial de $\mathrm{Na}, \mathrm{K}$ e Al (segundo De La Roche, 1968)

Na Fig. 5, embora haja uma pequena superposição entre os campos das grauvacas e basaltos, é possível, com maior clareza, a distinção entre os dois grupos litológicos. Desta forma, as rochas petrograficamente classificadas como granada-biotita xistos feldspáticos são seguramente de origem sedimentar grauvaquiana. De maneira semelhante, os granada-andaluzita-biotita xistos representam originalmente pelitos e os anfibolitos caem no domínio basáltico.

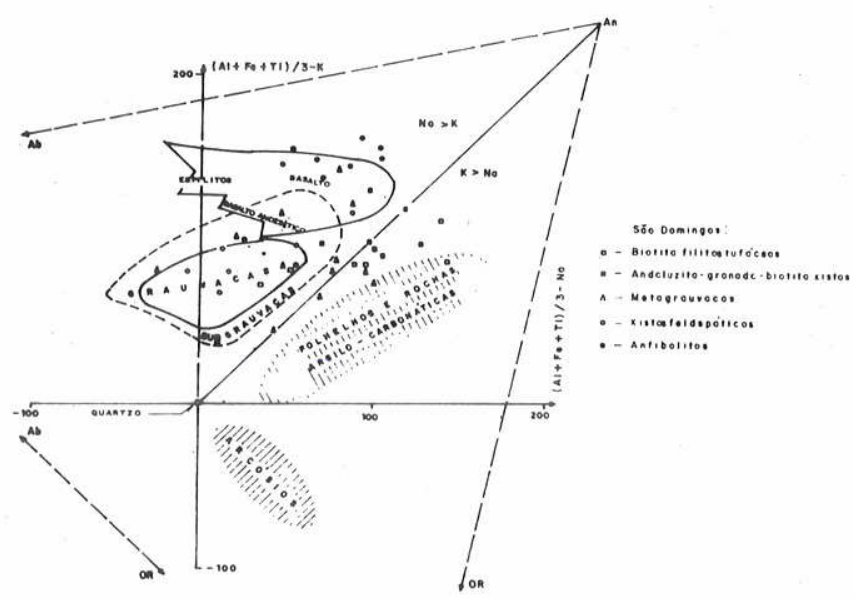

Figura 5-Dominio das rochas sedimentares e das rochas igneas básicas (segundo De La Roche, 1968)

Os metamorfitos da região de São Domingos são perfeitamente separados segundo seu caráter original (grauvacas e basaltos) pelo comportamento diferencial de $\mathrm{Ca}$ e $\mathrm{Mg}$, como se demonstra no gráfico da Fig. $6(\mathrm{Al}+\mathrm{Fe}+\mathrm{Ti}$ em função de $\mathrm{Ca}+\mathrm{Mg}$ ).

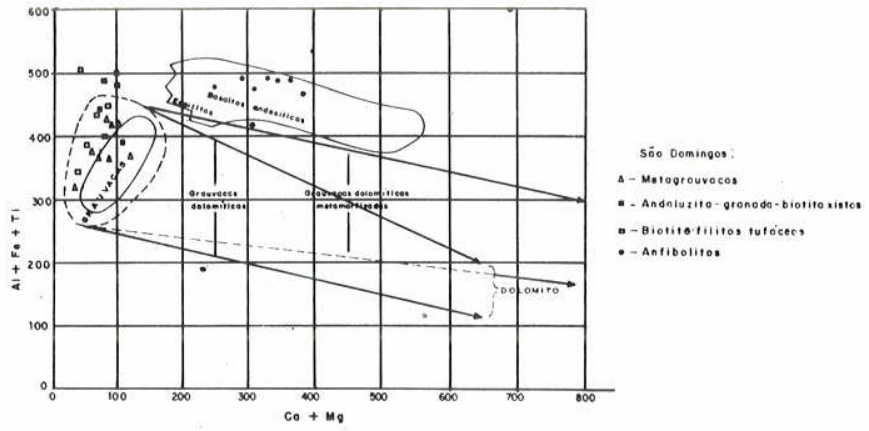

Figura 6 - Discriminação entre grauvacas ou grauvacas carbonatadas e rochas igneas básicas (Moine e Dé La Roche, 1968)

O conjunto de rochas plutônicas ácidas foi inicialmente analisádo pelo diagrama de La Roche (1966), $\mathrm{Si} / 3-(\mathrm{K}+$ $+\mathrm{Na}+2 / 3 \mathrm{Ca})$ vs. $\mathrm{K}-(\mathrm{Na}+\mathrm{Ca})$. Nesse gráfico (Fig. 7), constata-se que as amostras analisadas caem nos campos do tonalito, granito e quartzo diorito. Não foi diagnosticado granodiorito.

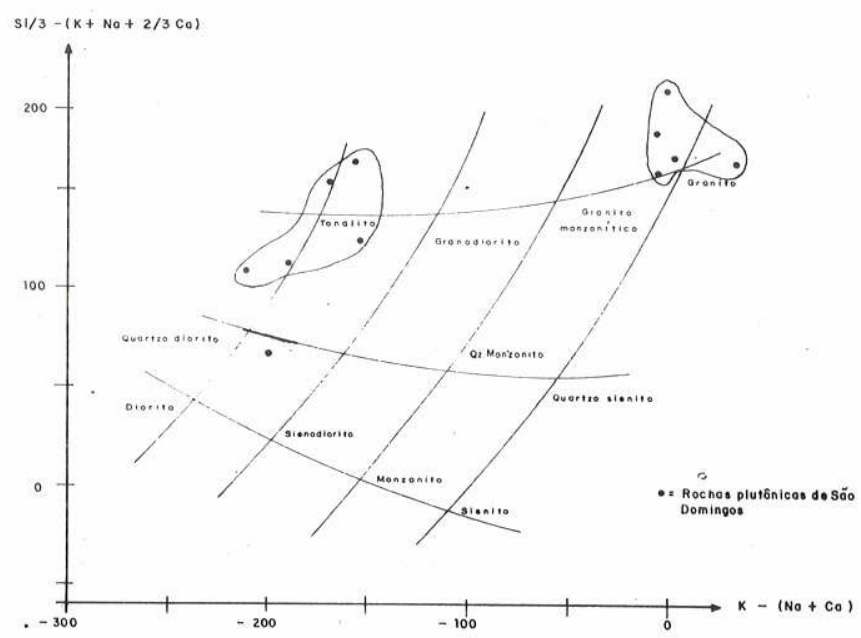

Figura 7-Diagrama de H. De La Roche (1966) que discrimina as séries plutônicas ácidas

Características do vulcanismo Com base nos dados químicos das rochas de São Domingos, procurou-se determinar a natureza e a filiação química do vulcanismo, o que, conseqüentemente, levaria a inferências mais seguras quanto à ambiência geológica da seqüência estudada. Modernamente, tem-se chegado à conclusão de que alguns regimes tectônicos possuem uma tipologia magmática específica. Portanto observações químicas aliadas a feições estruturais e à própria dimensão dos fenômenos aí representados constituem critérios indispensáveis para uma avaliação geológica e econômica.

Para esse estudo, foram utilizados os diagramas de Simpson (1954), Kuno (1968), Pearce et al. (1977) e Tegyer (1980).

Fundamentalmente, dois tipos de diagramas foram usados: aqueles para classificar as rochas vulcânicas em campos de referência, situando as principais famílias de rochas calco-alcalinas e alcalinas; e um outro tipo, em que foi possível discriminar as séries magmáticas, indicando as curvas de evolução ou os limites dos domínios petroquímicos correspondentes às diferentes linhagens. Os diagramas mais apropriados para diferenciar as associações magmáticas calco-alcalinas e tholéticas são os que ressaltam o caráter 
fracamente potássico da série tholeítica e o enriquecimento em ferro de seus termos básicos e intermediários.

A Fig. 8 evidencia o caráter tholético dos anfibolitos analisados, pois há um característico enriquecimento de ferro (veja a Curva 2 da Figura). Os pontos referentes às rochas metavulcânicas ácidas mostram proximidade da Curva 1 (calco-alcalino), sendo que a mesma apresenta convexidade inversa em relação aos tholeítos.

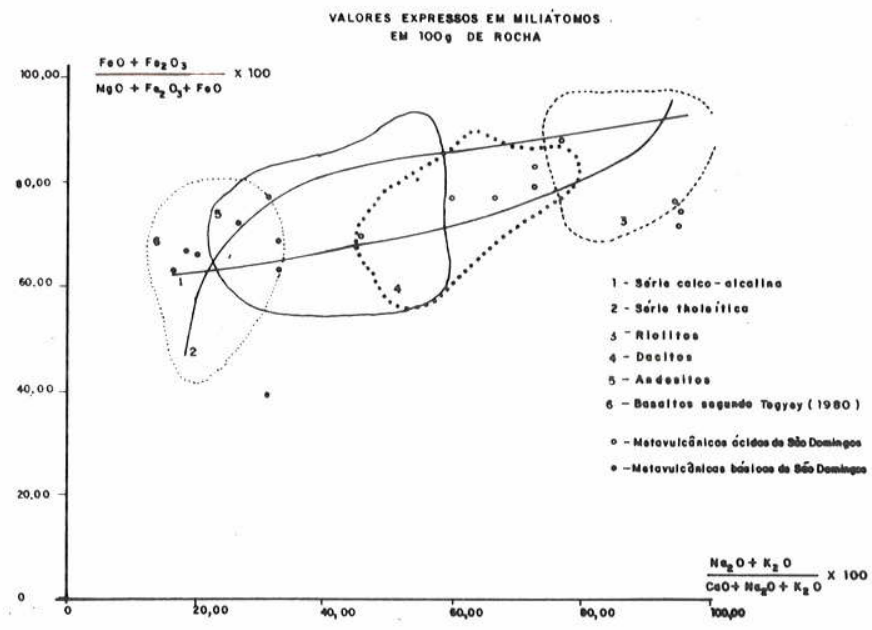

Figura 8-Diagrama de Simpson (1954) no qual é possivel separar as rochas da série tholeitica e calco-alcalina

A Fig. 9 (AFM) é um diagrama clássico utilizado para a separação das séries calco-alcalina e tholeítica, pois traduz muito bem o enriquecimento de ferro nos termos médios da série tholeítica. Em relação às amostras analisadas, julgamos satisfatória a identificação das duas séries e a caracterização dos anfibolitos como tholeíticos. O diagrama $\mathrm{MgO}$ vs. $\mathrm{FeO}+0,9 \mathrm{Fe}_{2} \mathrm{O}_{3}$ da Fig. 10 permite, da mesma forma, separar muito bem as linhagens calco-alcalina e tholeítica nas litologias de São Domingos.

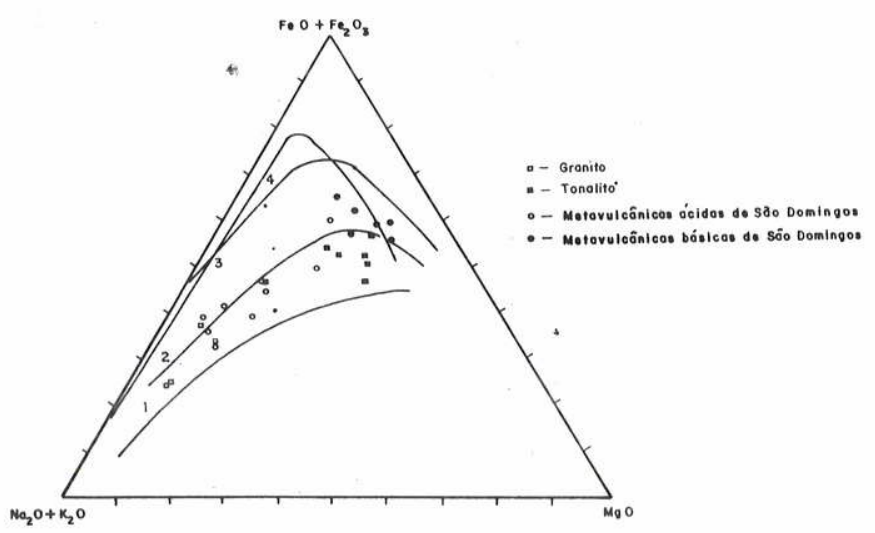

Figura 9-Diagrama AFM. Séries: 1-alcalina; 2-calco-alcalina; 3-tholeitica; 4-rica em aluminio

O índice de solidificação (IS) de Kuno (1968) da Fig. 11 permite avaliar o grau de diferenciação no interior de uma linhagem magmática. A variação de $\mathrm{SiO}_{2}$ em função do IS é muito regular na série calco-alcalina enquanto na série tholeítica cresce irregularmente, fracamente entre os termos básicos e intermediários, depois rapidamente ao nível das rochas diferenciadas. $\mathrm{O}$ diagrama $\mathrm{Al}_{2} \mathrm{O}_{3}$ vs. $\mathrm{SiO}_{2}$ (Fig. 12) coloca claramente em evidência duas linhagens: tholeítica

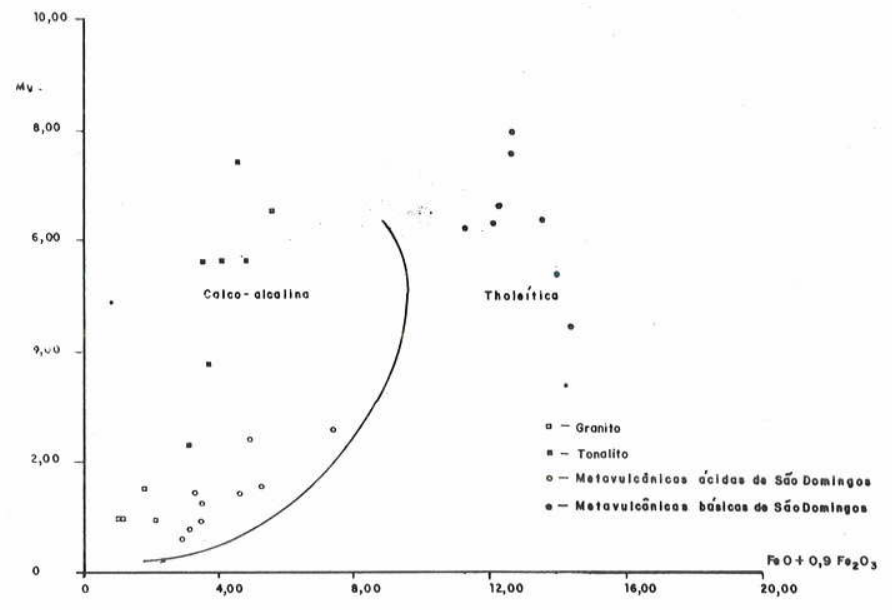

Figura 10 - Diagrama de Tegyey (1980) que permite discriminar as séries tholeitica e calco-alcalina.

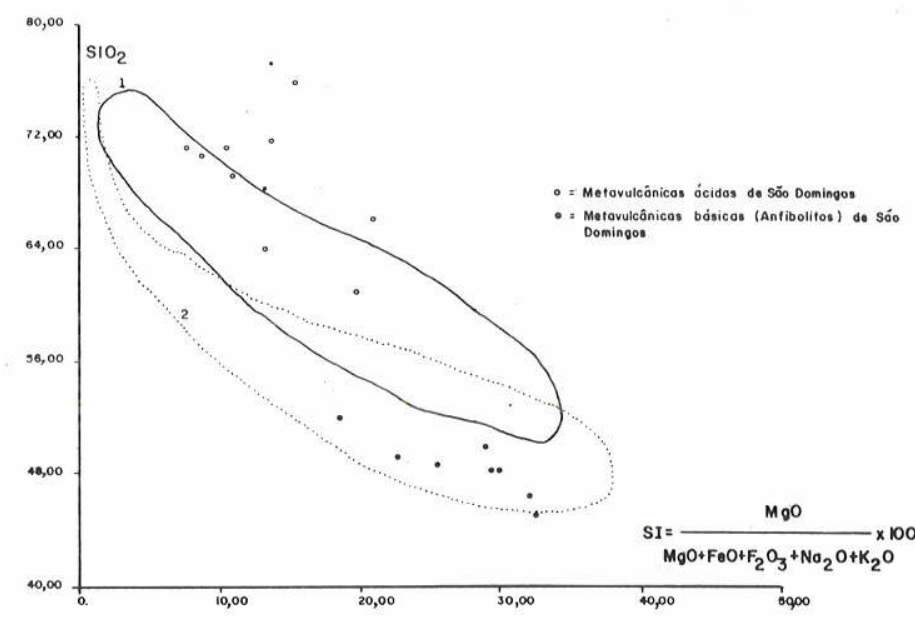

Figura 11 - Índice de solidificação de Kuno (1968). Campos de ocorrência das séries calco-alcalina (1) e tholeitica (2)

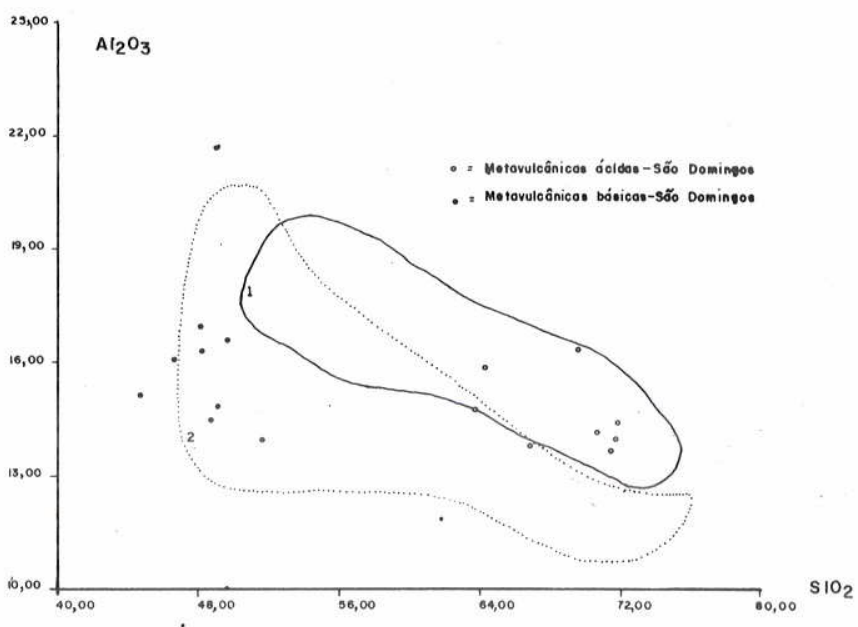

Figura 12. - Diagrama de Tegyey (1980) com separação das séries tholeitica (2) e calco-alcalina (I)

(pigeonítica) e calco-alcalina (hiperstênica). Há um ligeiro recobrimento para os termos ricos em alumínio (termos básicos e intermediários). $\mathrm{O}$ gráfico $\mathrm{K}_{2} \mathrm{O} v s$. $\mathrm{Na}_{2} \mathrm{O}$ (Fig. 13) evidencia o comportamento diferencial do sódio e potássio nas séries calco-alcalina, tholeítica e shoshonítica e a Fig. 14 enquadra os anfibólio xistos da região de São Domingos como de proveniência vulcânica continental. 


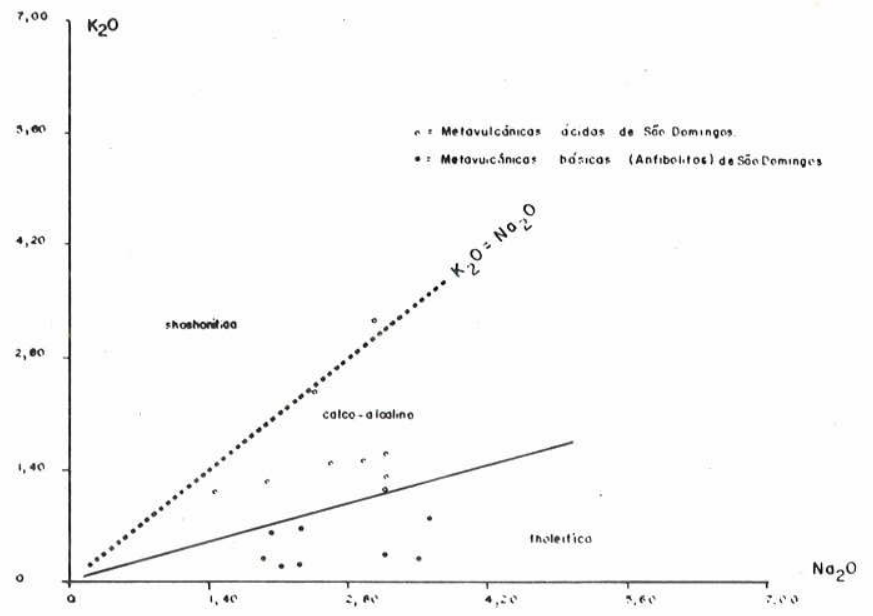

Figura 13 - Diagrama mostrando a separação das séries tholeitica, calco-alcalina e shoshonitica

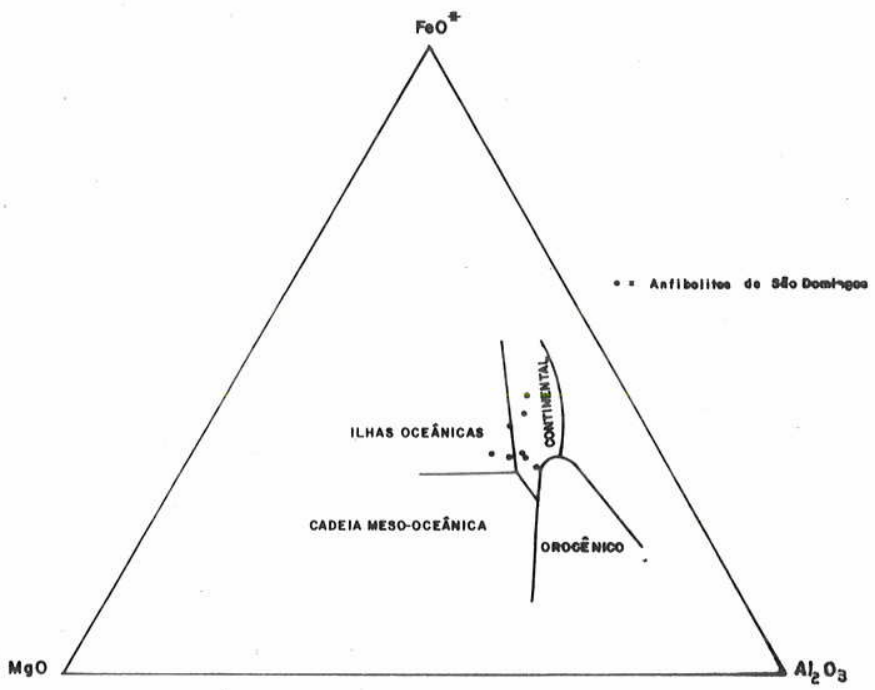

${ }^{*} \mathrm{FeO}$ como $\mathrm{Fe}$ total

Figura 14 - Gráfico de Pearce et al. (1977) que, pelo relacionamento dos óxidos de magnésio, ferro e alumínio, discrimina o campo de basaltos e seus respectivos ambientes geotectônicos

Concluindo, podemos mencionar que na região de São Domingos ocorrem manifestações vulcânicas básicas e ácidas representadas originalmente por basaltos, dacitos e riolitos. Os basaltos, invariavelmente, caíram no campo dos tholeítos enquanto os diferenciados ácidos sempre coincidem com a suíte calco-alcalina. Aparentemente, ocorrem duas manifestações vulcânicas distintas, pois os agrupamentos de pontos referentes aos basaltos, dacitos e riolitos se mostram sempre distanciados, sem termos intermediários (transicionais). É possível que haja uma estreita vinculação do plutonismo ácido com os diferenciados ácidos, estes desvinculados das restritas manifestações básicas. $\mathrm{O}$ vulcanismo aparentemente desenvolveu-se sobre uma crosta continental fina a partir de um rifteamento embrionário.

CORRELAÇŌES ESTRATIGRAFICAS Em função das características já citadas, há pelo menos três possibilidades de correlações estratigráficas para a seqüência litológica aflorante na região de São Domingos : 1) Grupo Araxá e seus correspondentes laterais de mais baixo grau metamórfico (grupos Araí, Canastra e Natividade); 2) seqüências vulcano-sedimentares arqueanas; e 3) Seqüência Tincunzal.
As litologias descritas na região de São Domingos são distintas das até então consideradas como pertencentes ao Grupo Araxá, principalmente no que se refere ao grau metamórfico e à composição original. Levando em consideração que neste grupo têm sido descritos fácies marginais de mais baixo grau metamórfico (Formação Canastra, grupos Araí e Natividade), seria aparentemente lógico admitir uma possível correlação. Entretanto existe também uma diferença acentuada em termos litológicos e estruturais entre a Seqüência de São Domingos e tais unidades, pois nelas são característicos os espessos pacotes quartzíticos maturos e níveis carbonáticos tidos como provenientes de uma deposição plataformal. Por outro lado, a sedimentação da Seqüência de São Domingos é essencialmente imatura, à base de grauvacas, com importantes eventos plutônicos e vulcânicos ácidos subordinadamente associados.

Na região de Dianópolis, Almas e Conceição do Norte tem sido caracterizado um conjunto de rochas metavulcânicas ácidas de natureza tufácea, sedimentos químicos ferruginosos (formação ferrífera) e anfibolitos, dispostos como estreitas faixas sobre o embasamento siálico. Tal seqüência é considerada como unidade de greenstone belt de idade arqueana (Costa et al., 1976; Correia F. ${ }^{\circ}$ et al., 1980).

A Seqüência de São Domingos mostra algumas características que lembram um posicionamento semelhante aos terrenos arqueanos; entretanto tais feições não são totalmente conclusivas, podendo também ocorrer em seqüências vulcano-sedimentares do Proterozóico Inferior. Apresenta-se como uma faixa estreita e alongada possuindo estratos intercalados de natureza sedimentar e vulcânica, regionalmente metamorfoseados no fácies xisto verde. Acha-se em contato com rochas siálicas e cortada por corpos plutônicos circulares de natureza tonalítica e granítica. Tectonicamente, mostra várias fases de deformação, salientando-se isoclinais com planos axiais verticalizados. Além disso são constatadas, na seqüência, mineralizações auríferas.

Tais características, se olhadas isoladamente, poderiam sugerir um posicionamento arqueano para a Seqüência de São Domingos. Entretanto são dignas de destaque as marcantes diferenças de tais unidades com as típicas seqüências de greenstone belt de Crixás, Guarinos, Goiás e Pilar, estas de idades inquestionavelmente arqueanas. Entre as diferenças pode-se citar a ausência, na Seqüencia de São Domingos, de lavas ultrabásicas, sedimentos químicos silicosos, tufos aluminosos e vulcanismo basáltico komatítico. Além disso, a proporção de vulcânicas nessa unidade é desprezível em relação aos sedimentos.

Quanto aos dados radiométricos que poderiam auxiliar no enquadramento estratigráfico da seqüência conhece-se apenas uma citação verbal de Barbosa (Simpósio do Cráton São Francisco) que atribui a idade de 1800 m.a. para os tonalitos pertencentes ao evento plutônico da Seqüência de São Domingos. Não foi mencionado o método utilizado, sendo impossível indicar qual o significado geológico da determinação. Há ainda uma datação de K/Ar em anfibolito colętado nas imediações da cidade de São Domingos (Hasui e Almeida, 1970) que indicou 2000 m.a.

A Formação Tincunzal, identificada por Marini et al. (1978), consiste em micaxistos, comumente grafitosos, com intercalações de gnaisses, meta-arcósios, quartzitos e metavulcânicas. Acha-se estratigraficamente entre o embasamento e o Grupo Araí. A seqüência litológica da área de São Domingos apresenta semelhança com os tipos líticos acima descritos no que se refere à deposição original e grau metamórfico. Contudo o argumento mais forte para essa possivel 
correlação é, sem dúvida, o mesmo posicionamento estratigráfico das duas seqüências.

Outro aspecto de suma importância é que, em outros locais (Campos Belos e Monte Alegre), a Formação Tincunzal se acha atravessada por pegmatitos e granitos estaníferos com xistos localmente graisenizados por efeito dessas intrusivas. Ao sul da cidade de São Domingos ocorrem também corpos de pegmatito mineralizados a cassiterita, embutidos em micaxistos localmente graisenizados. Há portanto, entre as duas seqüências, semelhantes litológicas, metamórficas, estratigráficas e metalogenéticas, sugerindo assim, uma possível correlação estratigráfica.

POTENCIALIDADE ECONÔMICA Na região ocorrem mineralizações de ouro e estanho (cassiterita). A cassiterita está vinculada diretamente a corpos de pegmatitos ácidos e graisens, situados ao sul da cidade de São Domingos. Como tais manifestações são seguramente co-genéticas às da região de Monte Alegre e Campos Belos, possuem alguma perspectiva. Em relação às ocorrências auriferas, estudos adicionais são necessários para indicar ou não sua contemporaneidade com as manifestações vulcânicas ácidas presentes na área.

A análise quanto às possibilidades de qualquer outro bem mineral na seqüência estudada terá que ser feita segundo uma perspectiva teórica, levando em consideração a estruturação geológica proposta. Em relação às mineralizações sulfetadas de zinco-chumbo-cobre, podemos estabelecer duas possibilidades: 1) depósitos vulcanogênicos; e 2) depósitos sedimentares.

O tipo 1, amplamente conhecido na literatura, mostra quase sempre relações diretas com um conjunto litológico específico (suíte vulcânica calco-alcalina) gerado em zonas marginais de placas, principalmente onde há consumo litosférico e formação de arcos insulares. Um outro tipo de depósito vulcanogênico, bem menos freqüente, relaciona-se com um conjunto vulcânico ácido calco-alcalino, no qual a ausência de andesitos constitui feição característica. O ambiente geotectônico, embora duvidoso, é considerado como zona de rift vulcânico ensiálico.

As características geológicas da Seqüência de São Domingos indicariam como maior possibilidade o segundo exemplo vulcanogênico, já que foi indicado como ambiente geotectônico uma calha ensiálica intracratônica, na qual ocorreu vulcanismo bimodal. Como esse é de natureza continental, ficam ainda mais restritas as possibilidades para jazidas sulfetadas.

No que concerne às possibilidades de jazimentos sulfetados sedimentares, há limitações ainda mais sérias já que não foi estabelecida com clareza uma compartimentação faciológica e ambiental da seqüência como um todo. De qualquer forma, a ambiência geotectônica proposta não inviabiliza uma perspectiva concreta de mineralizações, embora dados adicionais sejam necessários para uma análise mais apropriada.

Agradecimentos A Metais de Goiás S.A. (METAGO), na pessoa de seu Diretor Técnico, Wanderlino T. de Carvalho, pela liberação dos dados. Ao colega Sílvio C. Mattos por algumas discussões e ao professor Correia Neves, por ter fornecido parte da bibliografia aqui utilizada. Aos professores Reinhard A. Fuck e José C.M. Danni, pela revisão e sugestões.

\section{BIBLIOGRAFIA}

BARBOSA, O., BAPTISTA, M.B., DYER, R.C., BRAUN, O.P.G. COTTA, J.C. - 1969 - Geologia e Inventário dos Recursos Minerais do Projeto Brasília, DNPM/PROSPEC. Rio de Janeiro (inédito).

CONDIE, K.C. e HUNTER, C.R. - 1976 - Trace Element Geochemistry of Archean Granitic Rocks from the Barberton .Region, South Africa. Earth Planet. Sci. Lett. 29:389-400.

CORREIA F.ํ․ F.C.L. e SÁ, A.M. - 1980 - Projeto Natividade. Relatório Final DNPM/CPRM, 6. Goiânia (inédito).

COSTA, L.A.M., PORTELA, A.C.P., NILSON, A.A., VALE, C.R.O., MARCHETTO, C.L.M., SANTOS, E.L., MENEGUESSO, G., INDA, H.A.V., STERNA, L.H., MARCHETTO, M., BAPTISTA, M.B., FRATIN, O., MOSMANN, O., OLIV.EIRA, T.F. e SILVA, W.G. 1976 - Projeto Leste do Tocantins, Oeste do São Francisco. Relatório Final. DNPM/CPRM/PROSPEC. Rio de Janeiro (inédito).

FLOYD, P.A. - 1976 - Geochemical Variation in the Greenstone of S. S. England. Journal of Petrology 17, Part. 4, pp. 525-545

HASUI, Y. e ALMEIDA, F.F.M. - 1970 - Geocronologia do Centro-Oeste Brasileiro. Bol. Soc. Bras. Geol. 19(1):5-26. São Paulo.

JUNG, J. e BROUSSE, R. - 1962 - Les Provinces Volcaniques Néogènes et Quaternaires de la France. Bull. Serv. Carte Géol. Fr., t. 58, n. ${ }^{\circ} 267$. $61 \mathrm{pp}$

KUNO, H. - 1968 - Differentiation of Basalt Magmas. In: Basalts: The Poldervaart Treatise on Rocks of Basaltic Composition. Vol. 2, pp. 623-688. Intersci. Publishers. John Wiley and Sons, New York

LADEIRA, E.A., BRAUN, O.P.G., CARDOSO, R.N. e HASUI, Y. 1971 - O cretáceo em Minas Gerais. XXV Congr. Bras. Geol. Anais 1:15-31, São Paulo.

LA ROCHE, H. de - 1966 - Sur l'Usage du Concept d'Association Minérale dans l'Etude Chimique des Roches: Modèles Chimiques Statistiques, Représentations Graphiques, Classification Chimico-mineralogique. C.R. Acad. Sci. Paris, t. 262, pp. 1665-1668
LA ROCHE H. de - 1968 - Comportament Géochimique Différentiel de $\mathrm{Na}, \mathrm{K}$ et $\mathrm{Al}$ dans les Formations Volcanique et Sédi...ntaires. Un Guide pour l'Etude des Formations Métamorphiques et rilutoniques. C.R. Acad. Sci. Paris, Série D, t. 267, pp. 39-42

LETERRIER, J. e LA ROCHE H. de - 1972 - Extension aux Basaltes d'une Typologie Chimique des Roches Ignées Acides et Intermédiaires. C.R. Acad. Sci. Paris, t. 274, pp. 788-791.

MARINI, O J. LIBERAL, G.S. REIS, L.T TRINDADE, C.A.H e SOUZA, S.L. - 1978 - Nova Unidade Litoestratigráfica do Precambriano do Estado de Goiás. XXX Congr. Bras. Geol. Bol. 1:126-127, Recife.

MIYASHIRO, A. - 1975 - Classification, Characteristics and Origin of Ophiolites. Journ. Geol. 83:249-280

MOINE, B. e LA ROCHE H. de - 1968 - Nouvelle Approctie du Problème de l'Origine des Amphibolites à Partir de leur Composition Chimique. C.R. Acad. Sci., Paris, série D, t. 267, pp. 2084-2087

PEARCE. T.M., GORMAM, B.E. e BIRKETT, T.C. -1977 - The Relationship between Major Element Chemistry and Tectonic Enviroment of Basic and Intermediate Volcanic Rocks. Earth and Planet. Sci. Lett. $36: 121-132$

PEREIRA. E.L. - 1976 - Relatório de viagem. METAGO, inédito

POLI, A.J.C., MATOS, S.C. e TEIXEIRA, N.A. - 1981 - Geologia da Região de São Domingos, METAGO, inédito.

SIMPSON.E.S.W. - 1954 - On the Graphical Representation of Differentiation Trends in Igneous Rocks. Geol. Mag. 91:238-244.

TEGYEY, M. - 1980 - Utilisation de la Géochimie - Majeurs pour la Cartographie des Terrains Cristallins - Possibilités de Traitement Automatique des Analyses ou B.R.G.M. (inédito). 